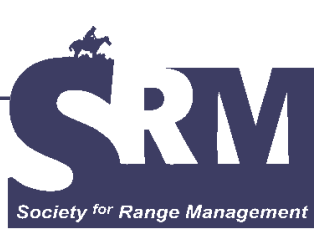

\title{
Annual Wheatgrass: A New Look at an Old Invasive Range Weed
}

\section{By James A. Young and Charlie D. Clements}

\section{Exotic, Invasive Range Weeds}

$\mathrm{I}$

f you wanted to write a book about exotic, invasive, annual rangeland weeds, the sagebrush/bunchgrass and salt desert ranges of the intermountain area of the - western United States is the place to come. Red stem filaree, Russian thistle, barbwire Russian thistle, annual kochia, tumble mustard, shield cress, prickly lettuce, bur buttercup, cheatgrass, and medusahead are just a few of the many annual species that have invaded rangelands of the intermountain area during the 19th and 20th centuries. Halogeton and bur buttercup are poisonous, while red stem filaree and cheatgrass are significant forage species. Cheatgrass and medusahead have markedly changed the chance of ignition and rate of spread of wildfires. The lowering of the interval between wildfires has been devastating to the native woody species of intermountain rangelands. All these exotic species have claimed their share of soil moisture, the scarcest of all environmental factors for plant growth on these semiarid to arid rangelands. In this environment, competition for soil moisture by alien annual species closes many plant communities to the establishment of seedlings of native perennial species, ensuring continued dominance of the alien species. This has been shown by numerous studies reaching back over 75 years of research.

\section{How Do We Acquire New Exotic Weeds?}

There is no reason to believe that this onslaught of exotic species is not going to continue through chance introduction and escapes from ornamental or environmental plantings. It is somewhat but not completely surprising that an alien species that has been present on western ranges for much of the 20th century has suddenly been recognized as a species that is rapidly increasing its range and the variety of environments it infests. The species is annual wheatgrass.

\section{Annual Wheatgrass}

In the 1935 edition of A. S. Hitchcock's Manual of Grasses of the United States, this grass was listed under the scientific name of Agropyron triticeum Gaetn. Hitchcock did not offer a common name and indicated the species was sparingly introduced in the Absaroka Forest of Montana and near Mountain Home, Idaho. The origin of the annual wheatgrass was given as southern Russia. When Agnes Chase revised the Manual of Grasses of the United States in 1950,

Common and scientific names of plants mentioned in this article.

\section{Common name}

Annual kochia

Annual wheatgrass

Bailey greasewood

Black greasewood

Barbwire Russian thistle

Bur buttercup

Cheatgrass

Crested wheatgrass

Needle grass

Prickly lettuce

Red stem filaree

Russian thistle

Shadscale

Shield cress

Tumble mustard

Winterfat (Russian)

Wyoming big sagebrush

\section{Scientific name}

Kochia scoparia Eremopyron triticeum

Sarcobatus baileyi

Sarcobatus vermiculatus

Salsola paulsenii

Ranunculus testiculetus

Bromus tectorum

Agropyron desertorum

Stipa

Lactuca serriola

Erodium cicutarium

Salsola targus

Atriplex confertifolia

Lepidium perfoliatum

Sisybrium perfoliatum

Krascheninnikovia

ceratoides

Artemisia tridentata ssp. wyomingensis 


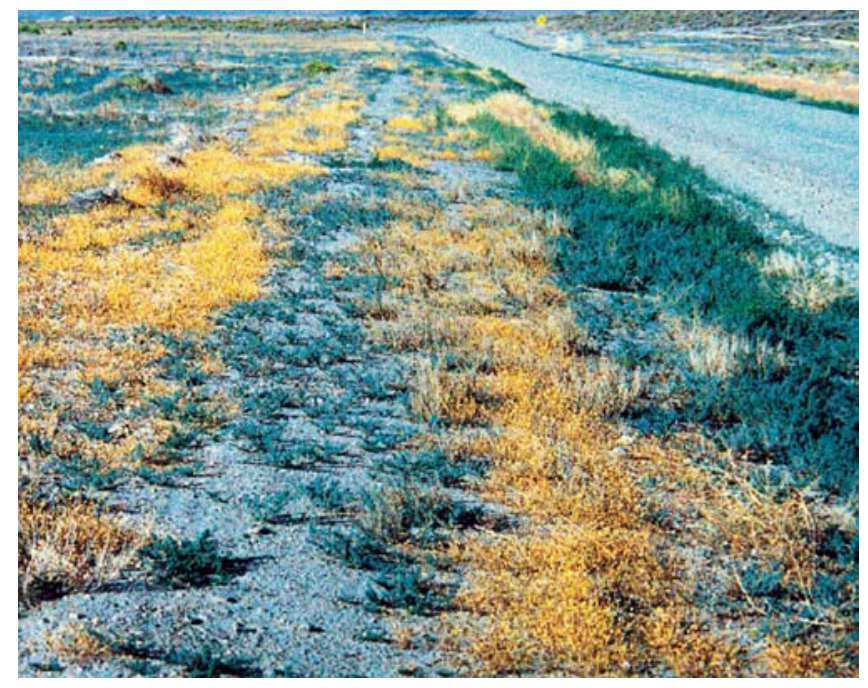

Figure 1. At maturity, for a brief period, annual wheatgrass plants have a golden color that is very distinct from cheatgrass. Image taken on Jungo Flat in Humboldt County, Nevada. The infestation is most abundant in the disturbed area along the road but extends well out in the surrounding salt desert vegetation. The green vegetation growing with the annual wheatgrass is halogeton.

Corfu, Washington, was added to list of known sites in the United States.

\section{Botanical History}

The botanical authority for Agropyron triticeum, Carl Friderich von Gaertner, was an 18th-century German physician and naturalist-botanist. He published the original description in 1770 from collections made in Russia. In 1934, Sergel Nevskii, senior agrostologist at the Botanical Institute of the Academy of Sciences of the USSR in Leningrad, published that the annual wheatgrass was not an Agropyron but belonged in the genus Eremopyrum. The genus Eremopyrum was established by Carl Friedrich Ledebour in his Flora Rossica published in the mid-19th century. Despite botanical names being written in Latin, the roots for the names Agropyron (agrios, wild; puros, wheat) and Eremopyrum (erem, desert; puros, wheat) are derived from ancient Greek. The specific name triticeum is the ancient Latin word for wheat. The scientific name for annual wheatgrass then becomes the redundant "desert wheat wheat." In the volume of the Flora Europaea containing the grass family, the characteristics used to separate the genera Agropyron and Eremopyrum are 1) that the glumes of the latter are joined at the base (connate), 2) that the rhachis (in the United States rachis, or axis of the spike) of Agropyron is tough (meaning it does not disarticulate or fall apart at maturity), and 3) that the Agropyron are perennials and the Eremopyrun are annuals. The Intermountain Flora volume on grasses used the genus name Eremopyrum triticeum and gave the distribution in the intermountain area as eastern Oregon, southern Idaho, northern Nevada, and central Utah.

\section{Native Environment}

In Flora Europaea, the distribution of Eremopyrum triticeum is given as steppes and other dry habitats in southeastern Europe from eastern Romania to western Kazakhstan and extending northward into central Russia and southeastward to southeastern Russia. The Bet Pac Dal Desert of Kazakhstan stretches across an immense expanse of central Asia east of the Aral Sea. Virtually every upland plant community that has been described in this desert contains, under the heading of ephemeral annuals, Bromus tectorum and Eremopyrum orientale. Bromus tectorum is, of course, our familiar invasive weed, cheatgrass. We have no common name for Eremopyrum orientale, but eastern annual wheatgrass would seem appropriate. It is a similar species to the annual wheatgrass introduced to North America, but the spike disarticulates at maturity between the individual florets in a manner similar to bottlebrush squirreltail. Eremopyrum triticeum is listed as a component of communities with woody sagebrush or winterfat overstories and a perennial grass layer dominated by species of needlegrass. The description of the native range of annual wheatgrass is like a broken record; it could fit most of the exotic, invasive annuals that have marched across the sagebrush/bunchgrass like Woody Guthrie's song about the boll weevil and the cotton patch, "Just looking for a home."

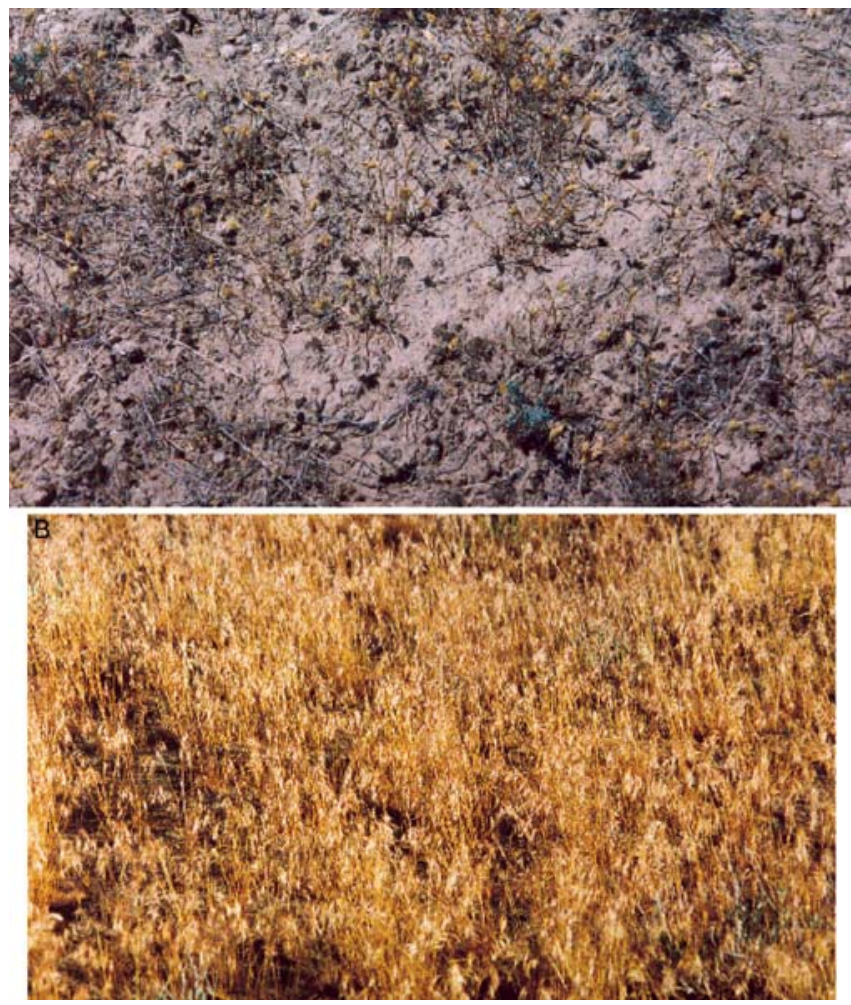

Figure 2. Comparison of mature annual wheatgrass $(\mathbf{A})$ and mature cheatgrass (B) The sparse leaves of annual wheatgrass disappear at maturity, leaving the naked stems and the upright spike. The spike soon dehisces as a unit, leaving the naked stems. The remnants of the annual plant are nearly invisible unless you look closely at the ground. In contrast, cheatgrass remains highly visible after maturity. 


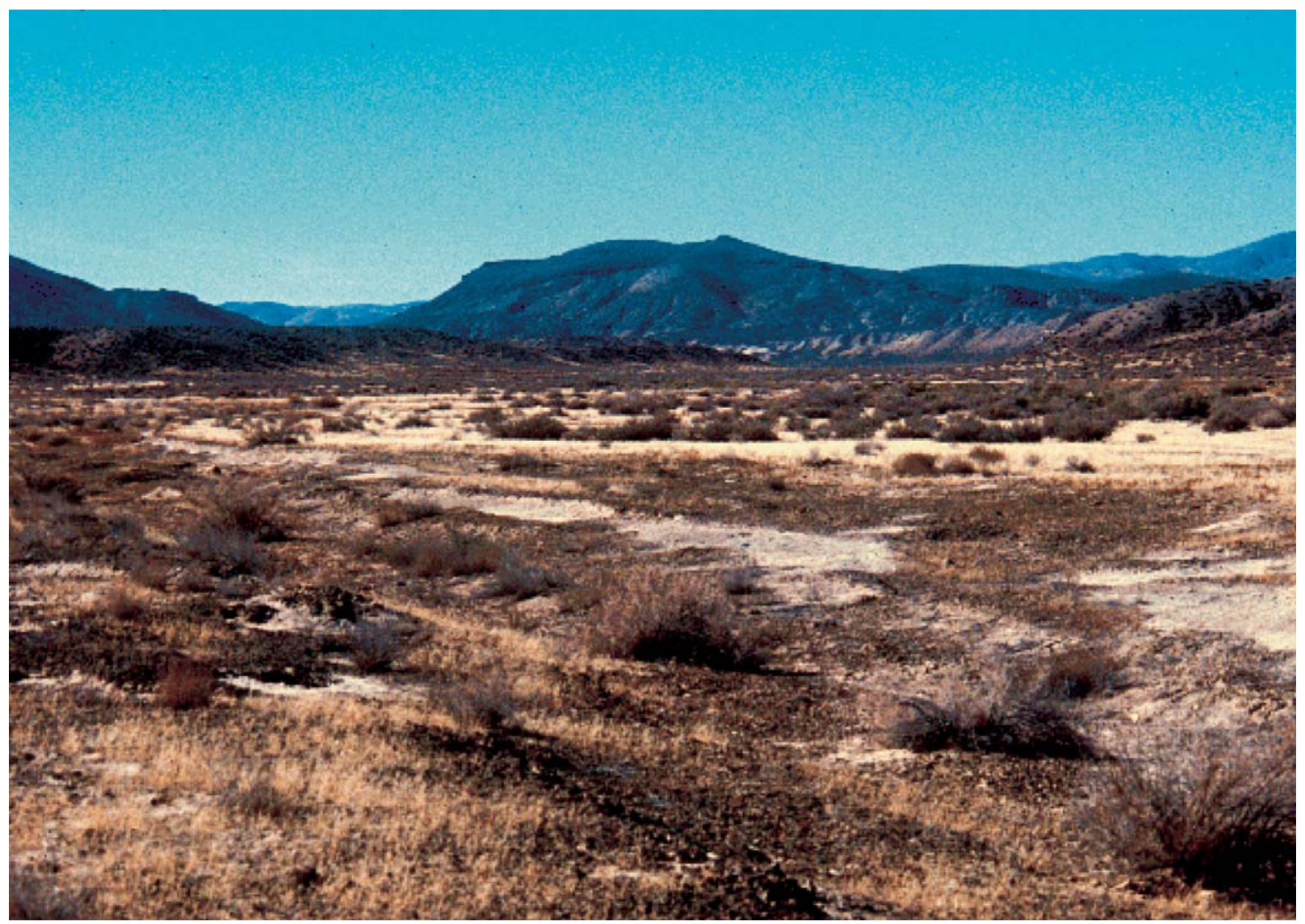

Figure 3. Annual wheatgrass infestation in Dixie Valley in north-central Nevada. At 3,700 feet, this is the lowest elevation in this portion of Nevada. The soil is salt-affected, very fine-textured deep-water sediment from the pluvial lake that occupied the basin during the Pleistocene. The salt desert plant community is Bailey greasewood. Image taken during the summer of 2003 after a winter with less than 3 inches of total precipitation. The annual wheatgrass matured and produced seed. Perhaps even more remarkable is that the cheatgrass under the shrubs in the background also produced seed at this site.

\section{Common Name}

The common name of annual wheatgrass is uniquely descriptive for this species in North America because there are no other annual wheatgrasses. The genus in Europe and Asia contains $5-8$ species. Apparently, only the single species has been introduced to North America. Many range managers know the weed as "annual crested wheatgrass." This is both to be expected and unfortunate. It is to be expected because the extremely compact spike of annual wheatgrass resembles the much larger head of some cultivars of crested wheatgrass. This comparison is unfortunate because although both species are members of the same tribe of grasses, they are not closely related. Annual wheatgrass is not an annual, dwarf form of crested wheatgrass.

\section{Seedling Identification}

The most abundant and widely distributed annual grass in the intermountain area is cheatgrass. The problem in identifying seedlings of annual wheatgrass is usually going to be how to separate seedlings of this grass from cheatgrass. If cheatgrass emerges in the fall, it forms flat rosettes of leaves over winter, and by midwinter the leaves often turn at least partially red. We have not observed either the rosettes or the red leaf color in fall-germinated seedlings of annual wheatgrass. The leaves of seedlings of both species tend to be flat, often with a slight twist. Cheatgrass leaves are slightly darker green in color, but this is not a real distinctive difference. The midrib on the underside of cheatgrass leaves is more prominent. The ligule of both species is papery, translucent, and minutely serrate. The Weed Science Society of America refers to downy brome as the common name for cheatgrass. Maturing cheatgrass plants are usually covered with a soft hispid pubescence. This covering is not necessarily well developed in seedlings. There are forms of cheatgrass that are without hairs (glabrous) at any growth stage. On balance, if an annual grass seedling in the intermountain area has hairs on the sheath, especially near the ligule, it probably is cheatgrass and not annual wheatgrass. 


\section{Flowering Plant Appearance}

As annual wheatgrass matures, it becomes very distinctive. At maturity, annual wheatgrass usually has a more golden straw-colored herbage than cheatgrass (Fig. 1). It is a much less leafy plant than cheatgrass. Unless cheatgrass is severely dwarfed by drought (Fig. 2), cheatgrass is a much taller plant than annual wheatgrass. The tallest annual wheatgrass plants we have seen in the field are around 6-8 inches. On dry years, the plants are often mature at 4 inches in height. On very arid sites, annual wheatgrass may mature and flower at 2 inches in height. Plasticity in morphology is readily apparent in exotic annual weedy grasses.

After maturity, when the seed head drops, annual wheatgrass essentially disappears (Fig. 3). The sparse leaves drop, and the naked stems fade in color until the dead plants are close to invisible unless you look closely. This disappearing aspect of the plant probably helps explain how the plant has invaded so many plant communities with minimum notice in the literature. Unless you visit the site during the couple weeks of the growing season when the seed heads are ripe and before they fall, you are not going to recognize the species unless you look closely.

\section{Seed Head Differences}

Annual wheatgrass is absolutely unique in its seed head. The spike is extremely compact with the florets set perpendicular to the central axis or rachis. The entire spike is less than an inch long and half an inch wide. The spike is oriented rigidly upright. This is strikingly different from the nodding open panicle of cheatgrass spikelets.

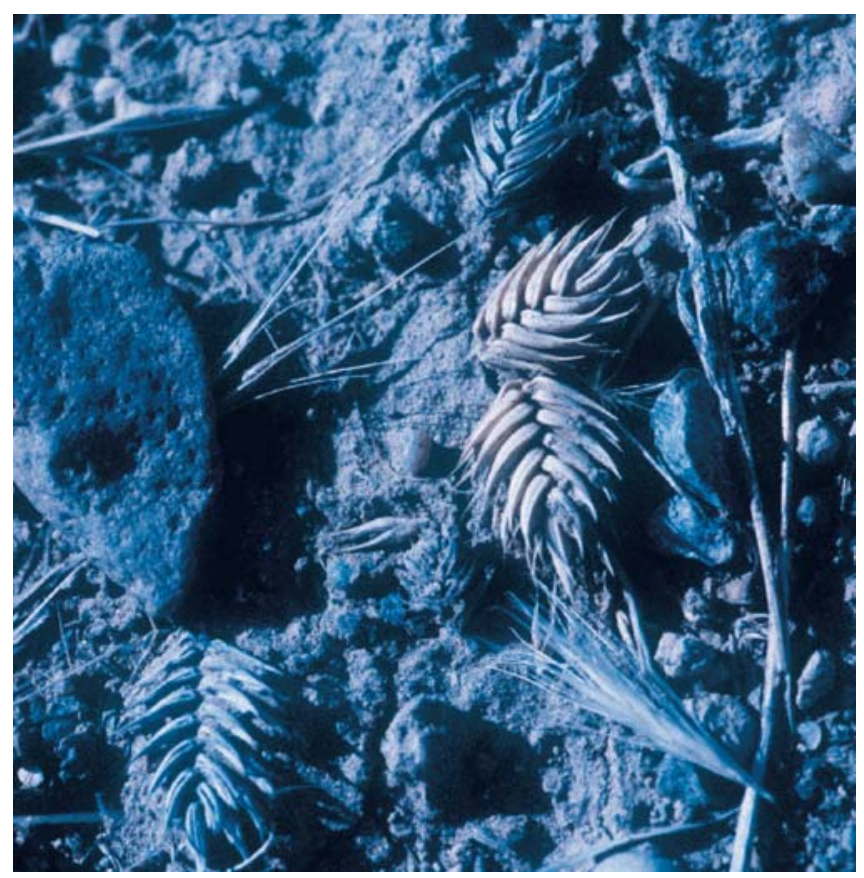

Figure 4. Spikes of annual wheatgrass on the surface of the seedbed. The entire spike dehisces as a unit. Note that there are both fresh and older spikes in the image. Apparently, the spikes, with seeds, can lay on the ground for more than 1 season if conditions are not favorable for germination.
The most appropriate description for the spikelets of annual wheatgrass is vicious. Press your finger against one of the mature spikelets, and the appropriateness of vicious is readily apparent. The glumes and lemma have very sharp, short, but needle-like awns.

\section{Seed Dispersal}

In initial seed dispersal, annual wheatgrass is unique even among the species of its own genus. The central axis of the spikelet disarticulates at the base, dropping the entire spikelet with the seeds (caryopses) intact. The description in the Intermountain Flora suggests that dehiscence of the seeds is tardy. In our experience, it is very tardy, with the spikelets containing seed remaining intact on the seedbed in the field for at least a couple years (Fig. 4).

In the greenhouse, seeds of annual wheatgrass readily germinate from intact spikelets. Such germination produces clumps of seedlings that are similar in appearance to those that occur from rodent scatter hoard caches of cheatgrass seeds (Fig. 5).

\section{Seed Germination}

Preliminary germination experiments in the laboratory indicate that the germination of annual wheatgrass seeds is equal to that observed in our extensive data bank for cheatgrass. Cheatgrass seeds have long been known to have exceptional germination at very cold and cold seedbed temperatures. This has been proposed as one of the competitive advantages the specie enjoys on rangelands, where moisture is restricted largely to the winter, when temperatures are too low for the growth of most species. Annual wheatgrass is at least equal to cheatgrass in germination at seedbed temperatures near freezing.

\section{Appearance of Seeds}

Searching for seeds of annual wheatgrass in a sample of crested wheatgrass would be difficult (Fig. 6). If skilled seed technologists were aware of annual wheatgrass seeds and had access to reference samples, they could probably identify annual wheatgrass seeds as a contaminant of crested wheatgrass seed lots. Some but not all annual wheatgrass seeds are darker at the base. Annual wheatgrass seeds are quite distinctive from seeds of cheatgrass.

\section{Range of Adaptation in the Intermountain Area}

The Flora Europaea uses the term "occasional species" to describe the distribution of annual wheatgrass outside its native range. Perhaps occasional opportunistic species fits this exotic weed. Given the chance of introduction to disturbed sites, it probably will grow just about anywhere in the intermountain area. We first noticed annual wheatgrass 40 years ago on the University of Nevada campus at Reno. A brief search revealed a distribution stretching northeast from the campus through the unpaved parking lots of the State Fair and Reno Rodeo grounds to vacant lots in residential areas. Pavement, buildings, and irrigated landscaping appeared to have wiped out this population, but it had 


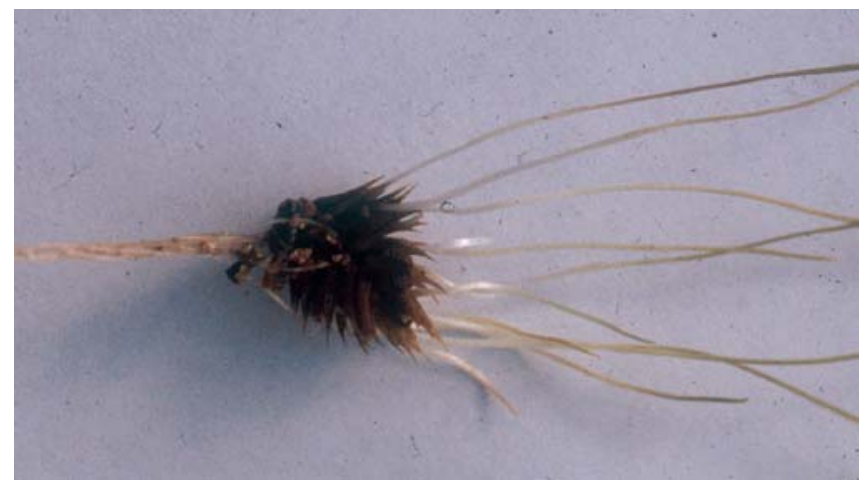

Figure 5. Spike of annual wheatgrass that was collected in the field from the soil surface and then placed in moist vermiculite in the greenhouse. Multiple seedlings emerged from the spike without the individual seeds dehiscing from the central axis.

migrated only to suburbia to the red clay soils on the ridge north of Reno and Sparks. Annual wheatgrass is well established in plant communities with yellow starthistle and medusahead.

Throughout his graduate student and professional career in Nevada, Dr P. T. Tueller has been an astute observer of the Great Basin rangelands for 50 years. He associates annual wheatgrass infestations with old crested wheatgrass seedings planted by the USDA Forest Service. These seedings were often placed in the higher environmental potential portions of the big sagebrush zone.

Our extensive surveys of the rangelands of northern Nevada have identified the transition zone between Wyoming big sagebrush and salt desert plant communities as the key environment for locating annual wheatgrass infestations. If you travel in the transition zone and see cheatgrass infestations in Bailey or even some black greasewood communities, you are almost certain to find annual wheatgrass. Shadscale communities with cheatgrass are also good places to look for annual wheatgrass.

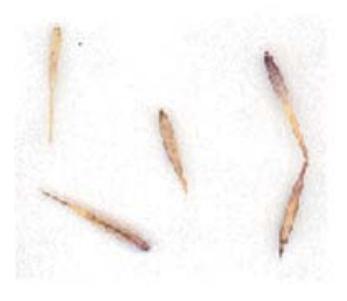

A

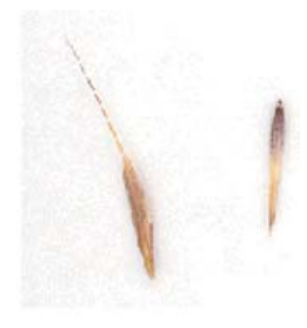

B
Figure 6. A, Seeds of annual wheatgrass. Each seed is about threeeighths to half an inch long. They are very similar in size to crested wheatgrass seeds. Many of the seeds are dark colored at the base, but some are straw colored, very similar to crested wheatgrass. B, Comparison of cheatgrass seed (right) and annual wheatgrass seed (left). Cheatgrass seeds are broader and flatter, and the much longer awn persists.

\section{Why Did Annual Wheatgrass Infestations Suddenly Increase?}

The classic ecological explanation for the sudden spread of annual wheatgrass on intermountain ranges is the lag phase in exotic species adaptation. As the exotic species grows in new environments, there is gradual natural selection for adaptation to the new site. Gradually, a threshold is crossed, the exotic species becomes invasive, and the populations seem to explode in distribution. Cheatgrass was first considered an incidental species that grew only in agronomic fields and along roadsides in rangeland environments.

Annual wheatgrass may also be a barometer of climatic change in intermountain rangeland environments. These changes could be on a very short-term and reversible scale or reflect longer-term significant changes in environmental potential. It is not obvious, but the expansion may also be a result of subtle changes in management or in wild herbivore or granivore populations.

We have previously mentioned that annual wheatgrass populations tend to disappear once the seed heads fall. Perhaps the increase in population distribution of this weed has been constant and their perception by human observers in a lag phase.

\section{Consequences of Annual Wheatgrass Invasion}

Mention the widespread occurrence of annual wheatgrass to field-level land managers, and they invariably ask in a nearpanicky voice, "Will it burn?" If you gathered enough of the herbage, you probably could get it to burn, but do not expect to get your hands warm. Annual wheatgrass produces so much less leafy herbage than cheatgrass that it probably is a minimal fuel hazard. During the late seedling stage, annual wheatgrass probably constitutes a minimal forage resource. At maturity, the armed spike eliminates any possibility of consumption by livestock.

The ecological importance of annual wheatgrass is that it illustrates that each seral stage in the continuum from Russian thistle and halogeton to exotic annual grass dominance is not a definite single-species dominance position but rather a true continuum of assemblages of species that can be broadened or made more diverse by new introductions. Each time this increase in exotic, invasive species occurs, the environmental potential of the site, most importantly soil moisture, is more fully appropriated to the exotic species, and the environmental potential available to seedlings of native species is equally lowered. Adding exotic, invasive species makes the process of environmental restoration on rangelands that much more difficult.

Authors are Rangeland Scientists, USDA, ARS, 920 Valley Road, Reno, NV 89502. 